\title{
How to Facilitate Implementation of Lean Concept?
}

\author{
Ramunè Čiarnienè \\ Kaunas University of Technology, Lithuania \\ Email: ramune.ciarniene@ktu.It \\ Milita Vienažindienè \\ Kaunas University of Technology, Lithuania \\ Email: milita.vienazindiene@ktu.It
}

\section{Doi:10.5901/mjss.2014.v5n13p177}

\begin{abstract}
The paper reveals to the challenges and barriers to be faced and overcomed while implementing lean concept. Lean manufacturing, lean enterprise, or simply "Lean", is a practice, which regards the use of resources for any work other than the creation of value for the end customer, as waste, and thus a target for elimination. Its main goals are to eliminate waste, reduce the need for managing large inventories, and provide optimum quality at the least cost by making quality control decisions an immediate part of the manufacturing process. Lean concept has been proven to be transferrable and applicable to a wide variety of industries and services. Although it is one of the popular concepts with a number of tools, techniques and technologies available to improve operational performance, and a lot of companies started implementing lean concept, only about ten percent or even less of the companies achieved significant results. The aim of the paper is to identify the main challenges and barriers that companies face with while implementing Lean concept and measures that could be taken to facilitate it. Synthesis of scientific literature allowed finding out the core principles of Lean concept. On the base of conducted analysis and synthesis, the main groups of barriers were identified and recommendations how to overcome them were presented. Authors of the paper present the conceptual model of Lean implementation process which includes success factors, barriers and progress measurement indicators. The results of this research can be useful for scientists analysing this topic from theoretical and empirical perspective, and for practicians implementing lean concept in business.
\end{abstract}

Keywords: Lean concept, implementation, barriers, progress indicators.

\section{Introduction}

Lean thinking originated within the Japanese automobile industry following Second World War and is principally based on the Toyota Production System (TPS), which was developed by a production executive named Taiichi Ohno and was used to improve the quality and productivity within Toyota Motor Company $(\mathrm{Ohno}, 1988)$. In an attempt to generalize the work of Toyota for other manufacturing settings, Krafcik (1988) coined the term "lean" to highlight the principles of limiting inventory and excess workers, or "waste", as opposed to other auto manufacturers' "buffered" approaches (Hopp \& Spearman, 2004; Staats, Brunner \& Upton, 2011). Later "Lean" was defined by Howell (2001) as "Give customers what they want, deliver it instantly with no waste".

Lean is an integrated system of principles, practices, tools, and techniques that are focused on reducing waste, synchronizing work flows, and managing production flows (Shah \& Ward, 2003; Narasimhan, Swink \& Kim, 2006; de Koning et al., 2006). The elimination of these non-value-added activities reduces cycle time and costs, which results in more competitive, agile, and customer-responsive organizations (Alukal, 2003).

Lean thinking increased in popularity in the 1990s. It has since been widely accepted and adopted across every industry ranging from automobiles to electronics and in the recent years, is being increasingly applied to a wide range of service organizations, including health insurance companies, hospitals, clinics, retail stores, etc. (Kumar, Choe and Venkataramani, 2013).

Various lean assessment surveys, such as Feld (2000), Conner (2001), and Jordan, Jordan Jr., \& Michel (2001), have been proposed to guide users through the lean implementation. For typical lean assessment tools, questionnaires are developed to survey the degree of adoption of lean principles.

While researchers disagree on the exact practices and their number, there is general consensus that there are four main aspects of Lean production, and they frequently group related practices together into bundles. These are practices associated with the quality management, pull production, preventive maintenance, and human resource management (Cua, McKone, \& Schroeder, 2001; Shah, Chandrasekaran, \& Linderman, 2008). Beside the lean tools, several 
performance metrics were developed to evaluate the improvements in lean implementation.

Comm \& Mathaisel (2000) describe leanness as a relative measure for whether a company is lean or not. Mclvor (2001) uses the term 'total leanness' to imply a perfectly lean state with several key dimensions of lean supply. SorianoMeier \& Forrester (2002) evaluate the degree of leanness of manufacturing firms using nine variables suggested by Karlsson and Ahlstrom (1996). Radnor \& Boaden (2008) summarize several interpretations of leanness, including an ideal state of lean, a context-dependent process, an ideal to be pursued, a condition of being lean, a particular state of the relationships between the facets of a system, and a journey to the ideal.

Though lean manufacturing has been widely recognised for its effectiveness in continuously improving productivity, product quality, and on-time delivery to customers; although a lot of companies started implementing lean concept, according to Bhasin \& Burcher (2006), only 10 percent or less of the companies succeed in implementing lean manufacturing practices. Despite significant studies and works on Lean manufacturing, this field has struggled with a lack of clarity about why Lean implementation is not so successful and what main barriers it faces with.

The aim of the paper is to identify the main challenges and barriers that companies face with while implementing Lean concept and measures that could be taken to facilitate it.

\section{Research Methods}

The analysis of scientific literature enabled to disclose the essence and importance of Lean concept. Synthesis of scientific literature allowed finding out the core principles of Lean manufacturing. Scientific literature was systemized and summarized by applying the logical, comparative and graphic representation. On the base of conducted analysis and synthesis, the main barriers were identified and recommendations how to overcome them presented. As a result of extensive literature review the model illustrating successful lean implementation process was presented.

\section{Findings}

\subsection{The General Principles of Lean Concept}

More than 25 years scientists are discussing about what constitutes Lean concept (Womack \& Jones, 1996; Emiliani et al., 2004; Spear, 2004; Murman et al., 2002; Hopp \& Spearman, 2004; Ciarniene \& Vienazindiene, 2012). Results of its retrospective analysis draw attention to five core principles of Lean, based on an underlying assumption that organizations are made up of processes (see table 1).

Table 1. The General Principles of Lean Concept

\begin{tabular}{|l|l|}
\hline Principles & Explanation \\
\hline 1. Identify Customers and Specify Value & $\begin{array}{l}\text { Only a small fraction of the total time and effort in any organisation adds value for the end } \\
\text { customer. By clearly defining value for a specific product or service from the end customer's } \\
\text { perspective, all the non-value activities - or waste - can be targeted for removal. Identifying } \\
\text { customers' value it is important to answer following questions: What do customers want? } \\
\text { When and how do they want it? What combination of features, capabilities, availability and } \\
\text { price will be preferred by them? }\end{array}$ \\
\hline 2. Identify and Map the Value Stream & $\begin{array}{l}\text { Firms map production (create a value stream) to ensure that each step provides value. The } \\
\text { Value Stream is the collection of processes and activities across all parts of the organisation } \\
\text { involved in jointly delivering the product or service. This represents the end-to-end process } \\
\text { that delivers the value to the customer. The Value Stream is not limited by boundaries } \\
\text { between companies; that are the reason to strive to integrate suppliers, manufacturers, } \\
\text { distributors and even retailers in the efforts to recognize and analyse the Value Stream. } \\
\text { Also, three main categories of activities are distinguished: a) those that add value; b) those } \\
\text { that do not add value but cannot be currently avoided; c) and those that do not add value } \\
\text { and should therefore be eliminated. }\end{array}$ \\
\hline 3. Create Flow by Eliminating Waste & $\begin{array}{l}\text { Flow reorganizes processes so products move smoothly through the value-creating steps. } \\
\text { Typically it is found out that only 5\% of activities add value, this can rise to 45\% in a service } \\
\text { environment. Eliminating this waste ensures that product or service "flows" to the customer } \\
\text { without any interruption, detour or waiting. In lean manufacturing, waste is not the object that } \\
\text { is tossed into the scrap barrel, but rather defined by what the customer will and won't pay for } \\
\text { and planning production around making the best part in the least amount of time. Processes } \\
\text { that do not add value, according to a customer's definition, are eliminated. }\end{array}$ \\
\hline
\end{tabular}




\begin{tabular}{|l|l|}
\hline 4. Respond to Customer Pull & $\begin{array}{l}\text { This is about understanding the customer demand and then creating process to respond to } \\
\text { this. Such that is produced only what the customer wants and when the customer wants it. } \\
\text { Companies should not push their products to customers, and rather let them pull "value" and } \\
\text { link all the production chain in such a way that materials are not released and activities are } \\
\text { not done until they are needed. }\end{array}$ \\
\hline 5. Pursue Perfection & $\begin{array}{l}\text { Perfection requires constant striving to meet customer needs and improve process with zero } \\
\text { defects. Creating flow and pull starts with radically reorganising individual process steps, but } \\
\text { the gains become truly significant as the entire steps link together. As this happens more } \\
\text { and more layers of waste become visible and the process continues towards the theoretical } \\
\text { end point of perfection, where every asset and every action adds value for the end } \\
\text { customer. It is the conviction that improvement efforts are never finished, and it is the } \\
\text { consistency to keep the discipline for improvement in place. }\end{array}$ \\
\hline
\end{tabular}

The benefits of Lean in the industrial world (both manufacturing and service) have been widely highlighted in the literature and include (Laureani \& Antony, 2012):

- Ensuring services/products conform to what the customer needs ("voice of the customer").

- Removing non-value adding steps (waste) in critical business processes.

- Reducing cost of poor quality.

- Reducing the incidence of defective products/transactions.

- Shortening the cycle time.

- Delivering the correct product/service at the right time in the right place.

\subsection{Readiness Factors and Barriers for Lean implementation}

Readiness factors are those essential ingredients which will increase the probability of success of Lean implementation. If the organisation is ready for embracing Lean initiative, then it should show some or many of the following attributes (Antony, 2013):

- employees are motivated intrinsically to achieve the new vision, mission and goals of the new initiative;

- employees show a "can do attitude";

- organisation is willing to take risk when it is appropriate;

- leaders of the organisation create a positive environment for change and when they can communicate to employees about the need for change and explaining explicitly about the challenges ahead of everyone in the organisation;

- leaders provide appropriate resources and recognise employees for small wins and big wins;

- leaders treat Lean as one of the top priorities and as a part of their continuous improvement strategy;

- management decisions are made based on facts and data but not gut-feeling or intuition;

- key business processes are clearly documented and accountabilities are clearly defined and communicated;

- the goals of Lean transformations are measurable, relevant and aligned with corporate goals;

- the organisation has relevant process performance metrics that all employees understand and use;

- the senior executives in the business understand the critical business processes and the performance metrics associated with them;

- the organisation has the culture of collecting relevant data which drives the process performance;

- the top talented people in the business are assigned to strategic projects which deliver measurable and quantifiable bottom-line results.

In reference to lean barriers, the principal literature promotes that often organisations fail to view lean as a continuous and never ending process (Bhasin, 2012; Saurin et al., 2011; Lewis, 2008; Atkinson, 2010). The lean transformations require a long-term commitment (Eisenhardt \& Martin, 2010); it is suggested that a minimum time frame of five years is required for an average sized company (Womack \& Jones, 2005; Sim \& Rodgers, 2009; Stamm, 2004; Ohno, 1988; Chappell, 2002). Lean should never be viewed as a manufacturing occurrence alone (Womack et al., 2003; Haskin, 2010; Emiliani, 2003; Cocolicchio, 2008; Eisenhardt \& Martin, 2010). Similarly, the objectives of lean for many organisations are often vague and confused (Singh et al., 2010). Often lean is viewed as a means to reduce waste, whereas it should be more about waste prevention and waste elimination (Bicheno \& Holweg, 2009; Sim \& Rodgers, 2009).

Z. Radnor et al. (2006) depict the following three types of barriers that organizations face with: 
1. The people issue-understanding the effect and gaining 'buy-in' of the individual particularly when there is a dilemma that 'persuading people to embark on the lean journey, where the last stop may be their own removal or reassignment isn't easy'.

2. The process issue-understanding which processes are applicable for Lean tools and techniques.

3. The sustainability issue - how to ensure that Lean becomes more than another set of tools but becomes an inherent way of working.

Slightly different classification presents M.F. Bollbach (2012); he discloses the social and the technical barriers to Lean implementation: high employee turnover, weak supplier performance, market conditions, lack of Lean knowledge, intercultural communication, and work styles.

Authors of this paper maintain that classification of barriers into social and technical is more acceptable. But technical barriers mostly depend on the organization. Summarizing Bhatia \& Drew (2007), Radnor \& Boaden (2008), Radnor \& Walley (2008), Brandão de Souza (2009), Alinaitwe (2009), Brandão de Souza \& Pidd (2011), Čiarnienè \& Vienažindienè (2012), Čiarniené \& Vienažindienè (2013), and Bollbach (2012), authors of this paper highlight two types of barriers: people related barriers and organizational barriers. The classification of main barriers to successful Lean implementation is presented in figure 1.

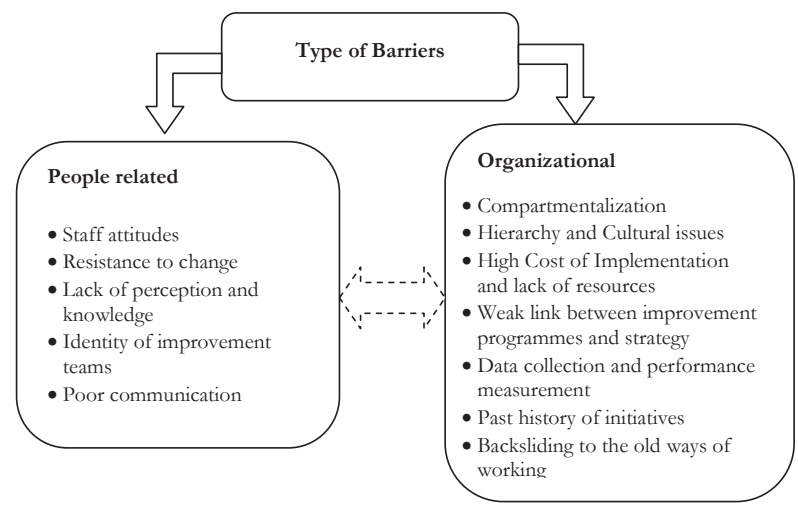

Figure 1. The Main Barriers to Lean Implementation

Implementing lean transformation often demands a significant change in an organization's staff attitude, which can be very challenging if an organization is not well slated to deal with the changes. Managers and employees can lack of understanding of lean knowledge, principles and techniques. Lean improvement programs are not incorporated into company's strategy. Improvement teams often are made up of those willing to get involved, rather than those who should do so. Based on the hierarchy of staff and the way management roles are allocated, it typically become a barrier for any improvement but this is care and also frequent roles especially important when lean is introduced. Implementing lean often means completely dismantling previous physical plant setups and systems. The purchase of efficient machinery and training employees can add considerably to companies' payroll expenses.

Presented classification of barriers to Lean implementation is very overall. Barriers can differ depending on the sector of economy and specific company. It can be said that every case of lean transformation is more or less unique, and companies face with some variety of barriers.

According to the empirical researches conducted at different companies implementing Lean concept (Deloitte \& Touche, 2002; Pirraglia, Saloni \& Van Dyk (2009); Bhasin, 2012), it can be depicted the main barriers, which prevent or delay Lean transformations:

- Backsliding to the old ways of working;

- Lack of implementation knowledge;

- Resistance by middle management;

- Lean is viewed as a fad;

- Resistance by supervisors;

- Resistance by hourly employee;

- Failure of past lean effort. 


\subsection{The Conceptual Model for Successful Lean Implementation}

Implementation of Lean philosophy and principles can be described as a set of actions and processes starting with planning the change, defining the readiness and success factors, possible barriers, implementation using Lean tools and techniques, and finishing by measuring the progress. Summarizing Martinez \& Perez (2001); Anchanga (2006); Pettersen (2009); Sim \& Rogers (2009); Radnor \& Boaden (2008); Duque \& Cadavid (2007); Upadhye, Deshmukh, \& Garg (2010); Bollbach (2012); Čiarnienè \& Vienažindienè (2012); Antony, 2013; Vienažindienè \& Čiarnienè (2013), authors of this paper present the model for successful Lean implementation (see figure 2).

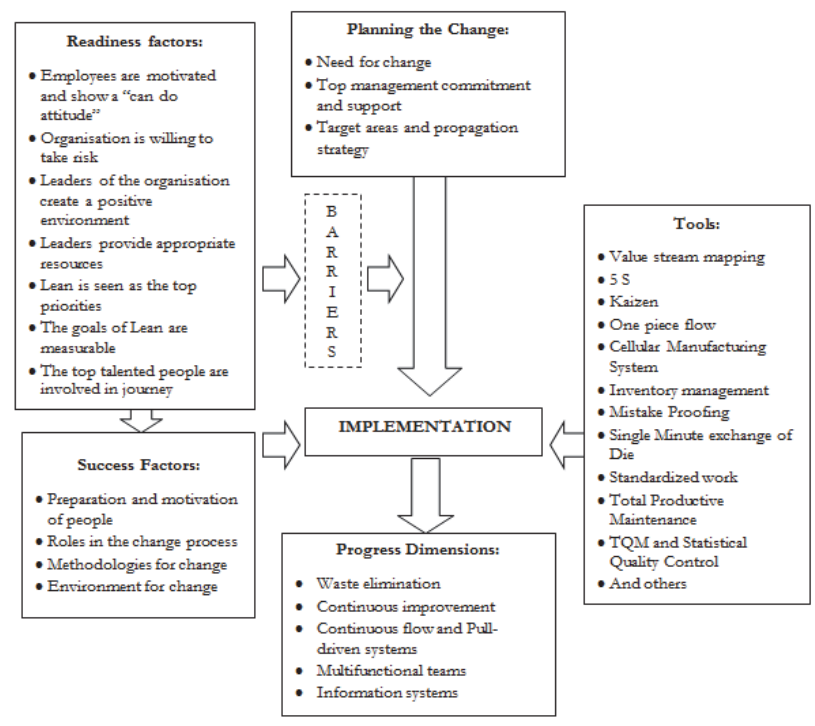

Figure 2. The Model for Successful Lean Implementation

Every organisation's lean journey starts under different circumstances, so there does not exist a unique recipe. Managers have to recognise that there is no simple formula or directives to follow which guarantees success.

Lean should not be viewed in the narrow sense of a set of tools, techniques and practices, but rather needs to be observed as a holistic approach that transcends the boundaries of the shop-floor, as a developing discipline and dynamic since it is constantly improving.

Benefits from lean are not easily quantifiable; it should be treated as a long term commitment with the ultimate goal being the need for it to be viewed as a philosophy. The tools and techniques that are normally associated with "lean" should be treated as a framework that enables the application of the thinking more natural for the organisation.

Finally, some general recommendations could be suggested.

Firstly, one of the major mistakes and reasons of unsuccessful implementing of lean concept is focusing on tools and techniques instead of sufficient consideration to personally related issues. It is very important to ensure efficient trust, human motivation and commitment at the organization among all the levels of employees.

Secondly, despite the fact that some authors describe lean in different levels of abstraction — philosophy, set of principles and bundles of practices - there should be very close interaction between them. Lean as a philosophy must be clearly understood and rated at the top managerial level, maintained through the main principles and implemented using different tools and techniques.

Thirdly, lean improvement programs have to be incorporated into the company's strategy.

\section{Concluding Remarks}

Summarizing scientific literature, Lean manufacturing can be described at different levels of abstraction: it can be defined as a philosophy, as a set of principles and as bundles of practices. According to the conducted analysis the following five core principles of Lean can be identified: specific value to the customer; value stream mapping wastes elimination; 
continuous improvement; continuous flow; and pull driven systems. These five dimensions can be measured to assess the progress in Lean transformation.

The analysis of scientific literature revealed that various authors emphasize slightly different barriers and challenges to lean manufacturing implementation. Authors of this paper suggest classification of barriers into two groups: people related barriers and organizational barriers. One of the major reasons for unsuccessful implementing of lean manufacturing is the typical behaviours exhibited by people in the workplace, which are known to be deficient trust and gain commitment.

Presented conceptual model describes implementation of Lean philosophy and principles as a set of actions and processes starting with planning the change, defining the readiness and success factors, possible barriers, implementation using Lean tools and techniques, and finishing by measuring the progress.

Every organisation is unique and depicts distinctive problems and constraints. Consequently organisations need to recognise and appreciate the concepts but are required to apply them in a context that is appropriate to the organisation.

\section{References}

Alinaitwe, H.M. (2009). Prioritising Lean Construction Barriers in Uganda's Construction Industry. Journal of Construction in Developing Countries, Vol. 14, No. 1, pp. 15-30.

Alukal, G. (2003). Create a Lean, mean machine. Quality Progress, Vol. 36 No. 4, pp. 29-35.

Anchanga, P. (2006). Critical success factor for lean implementation within SMEs. Journal of Manufacturing Technology Management, 17, pp. 11-17.

Antony, J. (2014). Readiness factors for the Lean Six Sigma journey in the higher education sector. International Journal of Productivity and Performance Management, Vol. 63, No. 2, pp. 257-264.

Atkinson, P. (2010). Lean is a cultural issue. Management Services, Vol. 54, pp. 35-44.

Bhasin, S. (2012). Prominent obstacles to lean. International Journal of Productivity and Performance Management, Vol. 61, No. 4, pp. 403-425.

Bhasin, S., \& Burcher, P. (2006). Lean Viewed as a Philosophy. Journal of Manufacturing Technology Management, 17(1), pp. 56-72.

Bhatia, N., \& Drew, J. (2007). Applying Lean production to the public sector. McKinsey Quarterly. No. 3, pp. 97-98.

Bicheno, J. \& Holweg, M. (2009). The Lean Toolbox. Picsie: Buckingham.

Bollbach, M.F. (2012). Country - specific barriers to implementing Lean production systems in China. [Online] http://hdl.handle.net/2134/10094 (January 20, 2013).

Bollbach, M.F. (2012). Country - specific barriers to implementing Lean production systems in China. [Online] http://hdl.handle.net/2134/10094 (February 2, 2014).

Brandão de Souza, L., \& Pidd, M. (2011). Exploring the barriers to lean health care implementation. Public Money \& Management, 31(1), pp. 59-66.

Chappell, L. (2002). Lean culture takes commitment. Automotive News, Vol. 76, pp. 471-3.

Čiarnienè, R., \& Vienažindienè, M. (2012). Lean manufacturing: theory and practice. Economics and management, 17 (2), $732-738$.

Čiarnienè, R., \& Vienažindienè, M. (2013). Lean manufacturing implementation: the main challenges and barriers. Management theory and studies for rural business and infrastructure development: research papers, 35 (1), pp. 41-47.

Comm, C.L., \& Mathaisel, D.F.X. (2000). A paradigm for benchmarking lean initiatives for quality improvement. Benchmarking: An Int. J., 7, 118-127.

Conner, G. (2001). Lean Manufacturing for the Small Shop. Society of Manufacturing Engineers: Dearborn, MI.

de Koning, H., Verver, J.P.S., van den Heuvel, J., Bisgaard, S. \& Ronald, J.M.M. (2006). Lean Six Sigma in healthcare. Journal for Healthcare Quality, Vol. 28 No. 2, pp. 4-11.

Deloitte \& Touche (2002). The road to world class manufacturing. [Online] Available: www.deloitte.co.uk (accessed 23 June 2011).

Duque, D.F.M. \& Cadavid, L.R. (2007). Lean Manufacturing Measurement: the Relationship between Lean Activities and Lean Metrics. Estudios gerenciales, 23, pp. 69-83.

Eisenhardt, K. \& Martin, J. (2010). Dynamic capabilities. Strategic Management Journal, Vol. 21, pp. 1105-22.

Emiliani, B. (2003). Better Thinking, Better Results. CLBM, New York, NY.

Emiliani, M.L. \& Stec, D.J. (2004). Leaders Lost in Transformation. Leadership and Organization Development Journal, 26 (5), pp. 370387.

Feld, W.M. (2000). Lean Manufacturing: Tools, Techniques, and How to Use Them. St. Lucie Press: Alexandria, VA.

Haskin, D. (2010). Allocating internal audit costs in a lean environment. Internal Auditing, Vol. 25, pp. 25-32.

Hopp, W.J. \& Spearman, M.L. (2004). To Pull or not to Pull: What is the Question? Manufacturing \& Service Operations Management, 6, 133-148.

Howell, G. (2001). Introducing Lean Construction: Reforming Project Management. Report Presented to the Construction User Round Table (CURT), Lean Construction Institute.

Jordan, J.A., Jordan Jr., J.A., \& Michel, F.J. (2001). The Lean Company: Making the Right Choices. Society of Manufacturing Engineering: Dearborn, Ml.

Karlsson, C., \& Ahlström, P. (1996). Assessing changes towards Lean production. International Journal of Operations \& Production 
Management, 16, 24-41.

Krafcik, J. F. (1988). Triumph of the lean production system. Sloan Management Review, 30, 41-51.

Kumar, S., Choe, D., \& Venkataramani, S. (2013). Reflective practice. Achieving customer service excellence using Lean Pull Replenishment. International Journal of Productivity and Performance Management, Vol. 62 No. 1, pp. 85-109.

Laureani, A., \& Antony, J. (2012). Standards for Lean Six Sigma certification. International Journal of Productivity and Performance Management, Vol. 61, No. 1, pp. 110-120.

Lewis, J. (2008). The changing face of manufacturing in the UK. Management Services, Vol. 52, pp. 11-19.

Martinez, A., \& Perez, M. (2001). Lean Indicators and Manufacturing Strategies. International Journal of Operations \& Production Management, 21, 1433-1451.

Mclvor, R. (2001). Lean supply: the design and cost reduction dimensions. Euro. J. Purch. Supply Man, 7, 227-242.

McKone, K.E., \& Schroeder, R.G. (2001). Relationships between Implementation of TQM, JIT, and TPM and Manufacturing Performance. Journal of Operation and Management, 19, 675-695.

Murman, E., et. al. (2002). Lean Enterprise Value: Insights from MIT's Lean Aerospace Initiative. New York: Palgrave.

Narasimhan, R., Swink, M., \& Kim, S.W. (2006). Disentangling leanness and agility: An empirical Investigation. Journal of Operations Management, 24, 440-457.

Ohno, T. (1988). Toyota Production System - Beyond Large-Scale Production. Productivity Press, New York, NY.

Pettersen, J. (2009). Defining Lean Production: Some Conceptual and Practical Issues. The TQM Journal, 21, 127-142.

Pirraglia, A., Saloni, D., \& Van Dyk, H. (2009). Status of lean manufacturing implementation on secondary wood industries including residential, cabinet, millwork, and panel markets. BioResources, 4, 1341-1358.

Radnor, Z., \& Boaden, R. (2008). Editorial: Lean in Public Services-Panacea or Paradox? Public Money \& Management, 28 (1), pp. 37.

Radnor, Z., \& Walley, P. (2008). Learning to Walk Before We Try to Run: Adapting Lean for the Public Sector. Public Money \& Management, 28 (1), pp. 13-20.

Radnor, Z., Walley, P., Stephens, A., \& Bucci, G. (2006). Evaluation of the Lean Approach to Business Management and its Use in the Public Sector. Edinburgh: The Scottish Government.

Saurin, T., Marodin, G. \& Ribeiro, J. (2011). A framework for assessing the use of lean production practices in manufacturing cells. International Journal of Production Research, Vol. 49, pp. 32-51.

Shah, R. \& Ward, P. (2007). Defining and developing measures of lean production. Journal of Operations Management, Vol. 25, pp. 785811.

Shah, R., Chandrasekaran, A., \& Linderman, K. (2008). In Pursuit of Implementation Patterns: the Context of Lean and Six Sigma. International Journal of production Research, 46, 6679-6699.

Sim, K. \& Rodgers, J. (2009). Implementing lean production systems: barriers to change. Management Research News, Vol. 32, pp. 3749.

Singh, B., Garg, S. \& Sharma, S. (2010). Development of index for measuring leanness. Measuring Business Excellence, Vol. 14, pp. 46-59.

Spear, S.J. (2004). Learning to Lead at Toyota. Harvard Business Review, Vol. 82, No. 5, 78-86.

Staats, B.R., Brunner, D.J., \& Upton, D.M. (2011). Lean Principles, Learning, and Knowledge Work: Evidence from a Software Services Provider. Journal of Operations Management, 29, 376-390.

Stamm, D.J. (2004). Kinda, sorta lean. Industrial Engineer, Vol. 36, pp. 22-6.

Upadhye, N., Garg, S. \& Deshmukh, S.G. (2010). Lean Manufacturing for Sustainable Development. Global Business and Management Research: An International Journal, 2, 125-137.

Vienažindienè, M. \& Čiarnienè, R., (2013). Lean manufacturing implementation and progress measurement. Economics and management, 18 (2), pp. 366-373.

Womack, J., \& Jones, D. (2005). Lean Thinking. Simon \& Schuster: London.

Womack, J., \& Jones, D.T. (1996). Lean Thinking: Banish Waste and Create Wealth in your Corporation. New York: Simon \& Schuster. Womack, J., Jones, D.T. \& Roos, D. (2003). The Machine that Changed the World. Simon \& Schuster: London. 